\title{
Research Notes
}

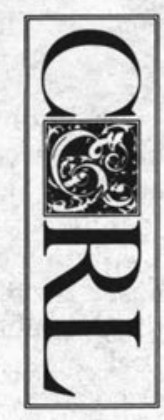

\section{The "Known" in Known-Item Searches: Empirical Support for User-Centered Design}

\section{Barbara M. Wildemuth and Ann L. O'Neill}

Traditionally, the catalog record for an item has been based on the cataloger's inspection of the item and has contained a complete description of the item. An alternative approach-user-centered design-would require the study of user behaviors and cognition related to interaction with the catalog and using the results of those studies to inform design decisions. To support known-item searches, one would need to study users' conceptions of the item being sought, what the user knows about the item, and which pieces of known information are viewed by the user as most appropriate for inclusion in a search. A pilot study was conducted to develop methods that can be applied to these questions. During the three phases of the study, 103 catalog users described 386 searches. Any written information known by the searchers was photocopied. The searchers generally knew the title, publication date, page numbers (particularly for journals), and/or the author (particularly for books). The information known by the searcher was usually accurate. Results from the study indicated that the method was feasible and valid, and provided a preliminary picture of knownitem searching in one library's catalog.

ome people who approach a library catalog have a particular item in mind, and they want to determine whether the library holds that item and where in the library it is located. Such a person would conduct a known-item search. A known- item search may include the author, the title, the subject, or a combination of these and other pieces of information to identify the item in the catalog. Inclusion of a piece of information in the knownitem search presumes that the searcher knows that piece of information.

Barbara M. Wildemuth is an assistant professor at the University of North Carolina School of Information and Library Science at Chapel Hill. Ann L. O'Neill is an instructor at the University of South Carolina's College of Library and Information Science. The authors would like to express their gratitude to Frederick G. Kilgour for raising the issues addressed in this paper and for his encouragement during the completion of this study. Funding for this study was provided by a Junior Faculty Development Grant from the University of North Carolina at Chapel Hill. 
Traditionally, the catalog record has been conceptualized as a surrogate for an item. Since all possible searches for that item cannot be anticipated, the goal is comprehensive description of the item based on the cataloger's inspection of it. Though attempting to serve the user's goals, the design of such a catalog is systemoriented, i.e., the designers use knowledge of the system (including the items being described) to design the catalog.

An alternative approach is user-centered design. ${ }^{1}$ Applying this approach would require the study of user behaviors and cognition related to use of the catalog and using the study results to inform design decisions. To support known-item searches, one would need to study users' conceptions of the item being sought (e.g., how vague/clear is the user's image of the item?), what the user knows about the item, and which known information is viewed by the user as most appropriate for inclusion in a search.

The pilot study described here was conducted to develop and test methods for determining (1) which data elements related to known-item searches are possessed by catalog users and (2) the utility of those data elements in conducting catalog searches. This study is a methodological precursor to a large-scale study of known-item searches. In addition, this article reports preliminary results from the pilot study.

\section{LITERATURE REVIEW}

Most studies of online public access catalogs (OPACs) have focused on user satisfaction, system features, interface design, system response time, or subject searches conducted. There have been only a few investigations of known-item searching, and even fewer studies of the information brought to the catalog to conduct a known-item search. The literature on known-item searches addresses three questions:

- What percentage of catalog searches are known-item searches?

- What types of errors occur in knownitem searches?

- What information do people bring to the catalog to search?
Transaction log analyses and surveys have been used most often to obtain data on OPAC use. Academic libraries have been investigated more frequently; however, a few public libraries were covered also.

Many of the studies that address known-item searching were conducted in the early 1980 s. Of particular note are the cross-institutional studies sponsored by the Council on Library Resources (CLR). ${ }^{2}$ At the time of these studies, OPACs were relatively new. Many search features have been improved in today's online catalogs and library users are more accustomed to OPACs. Therefore, the results reported in this review may not apply to today's catalogs and their users.

\section{What Percentage of Catalog Searches Are Known-Item Searches?}

Because transaction logs generally are examined after the search, it is impossible to determine the type of search reliably. ${ }^{3}$ Some people use either the author or title of a known work as a starting point in a subject search. The interpretation of keyword searches is also ambiguous. For example, MELVYL, the University of California OPAC, assumes that all title searches are keyword searches unless an exact-title command is specified. Some title keyword searches may actually be subject searches. John Akeroyd claims that searches performed solely to identify items on a particular subject may account for as much as 24 percent of all author/title searches. ${ }^{4}$ One study found that, of fifty searches, three author and two title searches ( 10 percent of the total) were actually subject searches, and another found that 43 percent of the catalog searches for a specific item were subject searches or hybrid subject/known-item searches. ${ }^{5,6}$ At Yale University, it was found that 73 percent of the card catalog users stated that they were looking for a specific item, but almost one-third of them believed they could find the desired information in some other publication. ${ }^{7}$ Conversely, a subject search could be conducted to identify a known item. 
A study based on researcher-specified queries found that 27 percent of the card catalog searches for the "Warren Report" began with a subject search, and a naturalistic study found that 6 percent of knownitem searches in a card catalog began with a search for a subject heading. ${ }^{8,9}$

In spite of the ambiguity involved, several studies have categorized the type of search conducted based on ex- amination of transaction logs (see table 1 ). In the table, author, title, and call number searches are considered knownitem searches. The row totals represent the proportion of all searches in the transaction logs that were known-item searches; the remaining proportion (not shown) were subject searches. The results are reviewed here, beginning with the most recent. At North Carolina State

TABLE 1

PERCENTAGE OF SEARCHES BY TYPE, BASED ON TRANSACTION LOG ANALYSIS

\begin{tabular}{|c|c|c|c|c|c|c|c|}
\hline \multirow[b]{2}{*}{ Study } & \multirow[b]{2}{*}{ Library } & \multicolumn{5}{|c|}{ Type of Known-item Search } & \multirow[b]{2}{*}{$\begin{array}{l}\text { Row } \\
\text { Total }\end{array}$} \\
\hline & & Author & $\begin{array}{c}\text { Title or } \\
\text { Series Title }\end{array}$ & $\begin{array}{l}\text { Author } \\
\text { and Title }\end{array}$ & $\begin{array}{c}\text { Title } \\
\text { Keyword }\end{array}$ & $\begin{array}{c}\text { Call } \\
\text { Number }\end{array}$ & \\
\hline Akeroyd, 1990 & $\begin{array}{l}\text { South Bank } \\
\text { Polytechnic }\end{array}$ & $24 \%$ & $55 \%$ & & & & $79 \%$ \\
\hline Akeroyd, 1990 & $\begin{array}{l}\text { Stirling } \\
\text { University }\end{array}$ & $35 \%$ & $21 \%$ & & $16 \%$ & & $72 \%$ \\
\hline Akeroyd, 1990 & $\begin{array}{l}\text { Polytechnic of } \\
\text { Central London }\end{array}$ & $18 \%$ & & $39 \%$ & $21 \%$ & & $78 \%$ \\
\hline Chang, 1986 & $\begin{array}{l}\text { University of North } \\
\text { Carolina }\end{array}$ & $27 \%$ & $27 \%$ & & & & $54 \%$ \\
\hline $\begin{array}{l}\text { Holmes and Bulger, } \\
1988\end{array}$ & $\begin{array}{l}\text { University of } \\
\text { Ottawa }\end{array}$ & $23 \%$ & $34 \%$ & $8 \%$ & $3 \%$ & $3 \%$ & $71 \%$ \\
\hline Hunter, 1991 & $\begin{array}{l}\text { NC State } \\
\text { University }\end{array}$ & $21 \%$ & $26 \%$ & & & $0 \%$ & $47 \%$ \\
\hline $\begin{array}{l}\text { Matthews, Lawrence } \\
\text { and Ferguson, } 1983\end{array}$ & $\begin{array}{l}\text { University of } \\
\text { California } \\
\text { (command mode) }\end{array}$ & $28 \%$ & $24 \%$ & & & & $52 \%$ \\
\hline $\begin{array}{l}\text { Matthews, Lawrence } \\
\text { and Ferguson, } 1983\end{array}$ & $\begin{array}{l}\text { University of } \\
\text { California } \\
\text { (lookup mode) }\end{array}$ & $30 \%$ & $41 \%$ & & & & $71 \%$ \\
\hline $\begin{array}{l}\text { Matthews, Lawrence } \\
\text { and Ferguson, } 1983\end{array}$ & $\begin{array}{l}\text { Northwestern } \\
\text { University }\end{array}$ & $31 \%$ & $38 \%$ & & & & $69 \%$ \\
\hline $\begin{array}{l}\text { Matthews, Lawrence } \\
\text { and Ferguson, } 1983\end{array}$ & $\begin{array}{l}\text { Claremont } \\
\text { Colleges }\end{array}$ & $35 \%$ & $18 \%$ & & & $2 \%$ & $55 \%$ \\
\hline $\begin{array}{l}\text { Matthews, Lawrence } \\
\text { and Ferguson, } 1983\end{array}$ & $\begin{array}{c}\text { Mankato State } \\
\text { University }\end{array}$ & $12 \%$ & $16 \%$ & $7 \%$ & $3 \%$ & & $38 \%$ \\
\hline $\begin{array}{l}\text { Matthews, Lawrence } \\
\text { and Ferguson, } 1983\end{array}$ & $\begin{array}{l}\text { Mission/West } \\
\text { Valley Colleges }\end{array}$ & $16 \%$ & $19 \%$ & $0 \%$ & & $2 \%$ & $37 \%$ \\
\hline $\begin{array}{l}\text { Matthews, Lawrence } \\
\text { and Ferguson, } 1983\end{array}$ & $\begin{array}{c}\text { Pikes Peak } \\
\text { Library District }\end{array}$ & $13 \%$ & $40 \%$ & & & & $53 \%$ \\
\hline Peters, 1989 & $\begin{array}{c}\text { University of } \\
\text { Missouri, Kansas } \\
\text { City }\end{array}$ & $23 \%$ & $1 \%$ & & $34 \%$ & $1 \%$ & $59 \%$ \\
\hline Tolle, 1983* & $\begin{array}{l}\text { Dallas Public } \\
\text { Library }\end{array}$ & $9 \%$ & $10 \%$ & $2 \%$ & & $3 \%$ & $24 \%$ \\
\hline Zink, 1991 & $\begin{array}{l}\text { University of } \\
\text { Nevada, Reno }\end{array}$ & $13 \%$ & $19 \%$ & & & & $32 \%$ \\
\hline
\end{tabular}

* In addition to subject searches ( 38 percent of the total), Tolle's data included Begin and End commands (18 percent each) and errors ( 2 percent). 
University 47 percent of the searches were for authors or titles, while 32 percent of the searches at University of Nevada, Reno, were for authors or titles. ${ }^{10,11}$ Author, series, and title searches for known items accounted for 56 percent of the searches at Stirling University, while searches for authors and titles accounted for 79 percent at South Bank Polytechnic, and searches for authors accounted for 18 percent at the Polytechnic of Central London (where all title searches were by keyword). ${ }^{12}$ Of the searches conducted on the University of Missouri Information Network, 24 percent were for authors or titles. ${ }^{13}$ Fifty-seven percent of the searches at the University of Ottawa were for an author or a title. ${ }^{14}$ In a preliminary study of the online catalog at the University of North Carolina at Chapel Hill, 27 percent of the commands were for author searches and 27 percent were for title searches. ${ }^{15}$ CLR study results indicated that over half the searches were for authors or titles at Northwestern University, the University of California, the Claremont Colleges and Pikes Peak [public] Library District, while only 28 percent of the searches at Mankato State University and 35 percent of the searches at the Mission/West Valley [community] Colleges were for authors or titles. ${ }^{16}$ Only 19 percent of the searches at the Dallas Public Library were based on authors or titles. ${ }^{17}$ As summarized in table 1, different studies have found quite different results in the number of author and title searches conducted.

Some systems support searches of author/title combinations. For example, at Ohio State University, derived author/title search keys (e.g., 4,4 or $4,3,3,2)$ make possible the author/title search feature. Combination author/title searches made up 39 percent of the searches at the Polytechnic of Central London, but were much less common at other libraries ( 8 percent of the searches at the University of Ottawa, 2 percent of those at the Dallas Public Library, and less than 1 percent of those at the Mission/West Valley Colleges). ${ }^{18-21}$

Other systems have a title keyword feature, allowing users to search for any word in a title, rather than being re- stricted to words at the beginning. The classification of these searches as knownitem searches particularly is open to question. Title keyword searches accounted for 16 percent of the searches at Stirling University, 21 percent at Polytechnic of Central London, and 34 percent at the University of Missouri-Kansas City. ${ }^{22-24}$ The same searches accounted for only 3 percent at the University of Ottawa and at Mankato State University. 25,26

Numeric searches for known items (e.g., using call number, ISSN, or ISBN) are a very small percentage of the searches. In most transaction log studies, numeric searches are attributed to staff and discounted from further analysis. When the percentage of numeric knownitem searches is reported, it ranges from less than 1 percent to 3 percent.

Surveys and interview studies of the types of catalog searches conducted are listed in table 2 . The percentages in this table represent the proportion of all the respondents that reported conducting each type of search; the remaining searches (not reported) were subject searches. These studies were more consistent in the proportion of known-item searches found: 48 percent at Ohio State University; 33-36 percent in the University of California system; and $41-50$ percent across the libraries participating in the CLRstudy. ${ }^{27-29}$ For comparison, an earlier study of card catalog use found that 56 percent of the users were looking for a specific document and 11 percent of the users were conducting searches for a particular author or for bibliographic verification. ${ }^{30}$

In summary, transaction logs have indicated that between 24 percent and 78 percent of OPAC searches are for authors or titles. Surveys have found that between 33 percent and 67 percent of the searches are for known items. Based on these data, it can be concluded that known-item searching is an important function that should be supported by a library catalog.

\section{What Types of Errors Occur in Known-Item Searches?}

In the studies cited here, a search statement generally is categorized as an error 
TABLE 2

PERCENTAGE OF SEARCHES BY TYPE, BASED ON INTERVIEW DATA

\begin{tabular}{|c|c|c|c|c|c|c|c|}
\hline \multirow[b]{2}{*}{ Study } & \multirow[b]{2}{*}{$\begin{array}{c}\text { Library } \\
\text { (Question Asked) }\end{array}$} & \multicolumn{5}{|c|}{ Type of Known-item Search } & \multirow[b]{2}{*}{$\begin{array}{l}\text { Row } \\
\text { Total }\end{array}$} \\
\hline & & Author & Title & $\begin{array}{c}\text { Author } \\
\text { and Title }\end{array}$ & $\begin{array}{c}\text { Known } \\
\text { Document }\end{array}$ & $\begin{array}{l}\text { Bibliographic } \\
\text { Verification }\end{array}$ & \\
\hline $\begin{array}{l}\text { Alzofon and Van } \\
\text { Pulis, } 1984\end{array}$ & $\begin{array}{l}\text { Ohio State } \\
\text { University } \\
\text { (command used) }\end{array}$ & $14 \%$ & $18 \%$ & $16 \%$ & & & $48 \%$ \\
\hline $\begin{array}{l}\text { Lawrence, Graham } \\
\text { and Presley, } 1984\end{array}$ & $\begin{array}{l}\text { University of } \\
\text { California } \\
\text { (information } \\
\text { brought to search) }\end{array}$ & $14 \%$ & $6 \%$ & $13 \%$ & & & $33 \%$ \\
\hline $\begin{array}{l}\text { Lawrence, Graham } \\
\text { and Presley, } 1984\end{array}$ & $\begin{array}{l}\text { University of } \\
\text { California } \\
\text { (purpose of search) }\end{array}$ & & & & $36 \%$ & & $36 \%$ \\
\hline $\begin{array}{l}\text { Lawrence, Graham } \\
\text { and Presley, } 1984\end{array}$ & $\begin{array}{l}\text { Multiple libraries } \\
\text { (information } \\
\text { brought to search) }\end{array}$ & $14 \%$ & $12 \%$ & $18 \%$ & & & $44 \%$ \\
\hline $\begin{array}{l}\text { Lawrence, Graham } \\
\text { and Presley, } 1984\end{array}$ & $\begin{array}{l}\text { Multiple libraries } \\
\text { (purpose of search) }\end{array}$ & & & & $50 \%$ & & $50 \%$ \\
\hline Lipetz, 1970 & $\begin{array}{l}\text { Yale University } \\
\text { card catalog } \\
\text { (purpose of search) }\end{array}$ & $6 \%$ & & & $56 \%$ & $5 \%$ & $67 \%$ \\
\hline
\end{tabular}

if it retrieves no citations. Most studies have not tried to determine whether zero-retrieval is due to the fact that the library does not hold the desired item. When such collection failures were taken into account, an adjusted error rate is reported. A few studies have defined errors based on an evaluation of the quality of the search statements, rather than the outcome of the search. ${ }^{31,32}$

Overall failure rate for known-item searches varies from study to study. In the CLR study, users were asked whether their searches were successful. Sixteen percent said that they did not find any of the items sought. ${ }^{33}$ Other studies estimated success based on transaction logs. Naturalistic studies conducted at Ohio State University found that 10 to 15 percent of the search sessions contained only errors, and that 17 to 25 percent of the title searches in departmental library catalogs were unsuccessful. ${ }^{34,35}$ Errors occurred in 37 percent of the title searches and 22 percent of the author searches conducted at Northwestern University. ${ }^{36}$ For 44 percent of the known-item searches in an online circulation system at the Univer- sity of Illinois, the item was not found, even though it was in the system. ${ }^{37}$

Several researchers examined search failures in more detail. In most studies, typographical errors or misspellings were frequent. At Northwestern University 54 percent of the errors in title searches, excluding collection failures, were typographical or spelling errors, and a reanalysis of a portion of that data found that 36 percent of the errors in author searches were typographical, excluding collection failures. ${ }^{38,39}$ Excluding collection failures, 60 percent of the errors in title searches and 30 percent in author searches on the University of Missouri Information Network were typographical errors or misspellings; the comparable error rates at the University of Nevada, Reno, were 37 percent of the unsuccessful title searches and 42 percent of the unsuccessful author searches. ${ }^{40,41}$ Even in a smaller study of experienced catalog users, 5 percent of the errors were typographical. ${ }^{42}$ Based on analyses of both failed and successful searches, two studies found that typographical errors occurred in 10 percent of the searches and another found that such errors oc- 
curred in 7 percent of the searches..$^{43,44}$ In summary, typographical errors or misspellings accounted for approximately one-third of the errors made in conducting known-item searches in online catalogs.

Another common error involved the search mode. In most catalogs the type of search must be specified prior to entering the search term, and users experience confusion about search mode (e.g., they enter an author's name while in subject search mode). Two studies conducted at the University of North Carolina found that the user's failure to specify a search mode accounted for 18 percent and 14 percent of the errors, respectively. ${ }^{45}$ At Northwestern University such errors accounted for 8 percent of the title search errors and 6 to 7 percent of the author search errors, excluding collection failures. ${ }^{46}$ The comparable rate at the University of Missouri was 16 percent. ${ }^{47}$ At the University of Nevada, Reno, mode errors occurred even more frequently, accounting for 60 percent of the errors among title searches, excluding collection failures. ${ }^{48}$ The wide variation in the rate of mode errors is most likely due to differences in catalog design, i.e., the visible cues for specifying search type.

In author searches, a frequent error was to leave the name uninverted (e.g., Mark Twain instead of Twain, Mark). Excluding collection failures, 36 percent of the errors in author searches at the University of Nevada, Reno, could be attributed to uninverted names. ${ }^{49}$ The comparable error rate at Northwestern University was 22 to 24 percent; and at the University of Missouri was 19 percent. $^{50,51}$ At the University of Ottawa, name inversion errors occurred in 6 percent of the author searches. ${ }^{52}$

A frequent error in title searches was the inclusion of an initial article in the search term, accounting for 20 to 26 percent of the errors at the University of North Carolina at Chapel Hill, and for 26 percent at Northwestern University, excluding collection failures..$^{53,54}$ Only these three studies examined this type of error, but the results are strikingly consistent and show a high failure rate.
In summary, users are unsuccessful in approximately one-quarter of their known-item searches. Researchers attribute these search failures to a variety of causes. The most consistent finding is that many typographical and spelling errors are made. In addition, users experience difficulty in expressing bibliographic information in the form required by the catalog and in handling command syntax.

\section{What Do Users Bring to the Catalog to Search?}

Empirical data concerning the bibliographic information brought to a search of an online catalog are almost nonexistent. The CLR study examined this issue in the most detail, asking catalog users what information they possessed (author, partial author, title, partial title, subject heading, etc.) and which information they used in their search ${ }^{55}$ David Holmes and Derrick Bulger reported that very few searches incorporated more data than that included in a brief cataloging record, i.e., bibliographic elements other than author, title, date, or call number. ${ }^{56}$ Jerry Specht asked subjects what information they brought to the search, but reported this information only as "known-item" or "location" search..$^{57}$ Two earlier studies, included in this review, were conducted of the bibliographic information users brought to searches of a card catalog. ${ }^{58}$

The CLR survey indicated that, across both known-item and subject searches, 50 percent of the users knew the author's name, and 48 percent knew the title..$^{59}$ Earlier studies of card catalog use delved more deeply into the completeness and accuracy of the bibliographic data possessed by users. At Yale University 77 percent of those conducting known-item searches knew the author, 97 percent knew the title, and 59 percent had date information. However, only 42 percent had completely accurate author information, only 62 percent had accurate title information, and only 29 percent were within one year of the correct publication date. ${ }^{60}$ In a study of known-item searches at three university libraries and one public library, 70 percent of the titles 
were complete and accurate and 60 percent of the authors' last names were complete and accurate. ${ }^{61}$ These results should be applied to OPAC design with caution, however, because "minor discrepancies" in spelling were disregarded. ${ }^{62}$ These discrepancies might not disturb card catalog searches but could result in failure of an online catalog search.

From these studies, it can be concluded that people often bring basic bibliographic data to the catalog, but that there are often inaccuracies in the data, some of which have significant negative effects on the search outcomes.

\section{RESEARCH QUESTION}

The research reviewed above indicates that known-item searches account for a significant proportion of online catalog searches. Therefore, it is worthwhile to try to improve users' effectiveness in conducting such searches. It is also clear that typographical and spelling errors are often the cause of search failures. Based only on an examination of transaction logs, it cannot be determined whether these spelling problems are related to the user's typing skills or the inaccuracy of the bibliographic data they possess. Studies of card catalog use indicate that users often have basic bibliographic data available to support their searches, but their data often contain inaccuracies.

In a user-centered approach to catalog design, all these findings are helpful. However, gaps in our knowledge remain. The current study was intended to test a method for addressing three research questions: (1) Of the many data elements that could be used to describe a bibliographic entity, which data elements do users bring with them to support their known-item searches? (2) How accurate is their recording or memory of those data elements? and (3) How successful are OPAC searches that employ those data elements? ${ }^{63}$

\section{METHOD}

In order to develop a method for addressing these research questions, an interview protocol was developed to determine what type of search the user was conducting, which data elements the user possessed prior to beginning the search, and whether the user considered the search successful. (The interview results will be integrated with transaction log analysis when the full-scale study is conducted in order to evaluate the relationship between the bibliographic data possessed and that used in the search.) This section describes the final instrument and the evolution of the interview protocol over three phases of data collection. In the next section, the preliminary results generated during the pilot study are reported.

All the interviews were conducted in Davis Library at the University of North Carolina at Chapel Hill (UNC). Data collection periods were approximately 1.5 to 2 hours and were staggered to cover class changes. Data collection was scheduled at different times between 10:00 a.m. and 8:00 p.m. to determine periods of heavy use. The online catalog software was a customized version of the catalog available from Data Research Associates (DRA). Public online catalog terminals were available on the main floor of the library and on each floor of the library stacks. During each threeday data collection phase, one of the investigators was stationed near the catalog terminals.

Respondents were selected from those who approached the terminal area but had not yet started their search. With the exception of library staff, repeat users, and students working in groups, every person that approached a terminal while the investigator was not occupied with another respondent was invited to participate in the study. Only those who said they were searching for known items ("an author," "a book," "a journal") were asked all questions.

The first draft of the survey instrument was derived mainly from questions on the CLR study survey. ${ }^{64}$ Questions were open-ended to accommodate the full range of responses. The interview covered the type and purpose of the respondent's search(es), the bibliographic information possessed by the respon- 
dent (either written or remembered), the respondent's evaluation of the success of the search, and the discipline and academic status of the respondent.

The first set of interviews was conducted in mid-October 1993. If the respondent brought written information to the terminal, permission was asked to photocopy that information (a desktop copier was moved to the online terminal area for this purpose). If the respondent did not have written information, all information known about the desired item(s) was recorded, spelled as reported by the respondent. After the search was completed, the respondent was asked whether the desired item was found and, if not, whether other items of interest were identified.

The second set of interviews was conducted in early November. In this phase, response categories were specified for all questions, call number verification was added as a type of search, and the interviewer asked in more detail about the bibliographic information known and the source of that information.

The third and final set of interviews was conducted in mid-November. By this time, all questions were closedended. For several questions, an "other" response category was still available and, where appropriate, the interviewer specified the user's response. The final form of the interview protocol is included in the appendix.
In addition to the interviews, the data reported in the next section include the outcomes from a replication of each search by a member of the research team, based on the information possessed by the user at the time of the interview. The outcomes of these searches can then be compared with the outcomes reported by the respondents at the completion of their searches.

\section{RESULTS}

One hundred eighty-three people were invited to participate in the study. Of this number, 58 ( 32 percent) were conducting subject searches and 22 (12 percent) declined participation, resulting in 103 interviews of people conducting known-item searches.

Table 3 presents the academic status and academic departments represented among the 103 respondents. Approximately three-quarters of the respondents were students, split fairly evenly between undergraduate and graduate students. The individual academic departments represented most frequently were English (9), psychology (9), education (7), political science (7), and sociology (7). The prevalence of departments in the social sciences and humanities can be attributed to the fact that these departments are primarily served by Davis Library, while many of the departments in the natural sciences (including the health sciences) have departmental libraries.

TABLE 3

ACADEMIC STATUS AND DEPARTMENT OF RESPONDENTS

\begin{tabular}{lrrrrr}
\hline Department & Faculty & $\begin{array}{r}\text { Undergraduate } \\
\text { Student }\end{array}$ & $\begin{array}{r}\text { Graduate } \\
\text { Student }\end{array}$ & $\begin{array}{r}\text { Local/ External/ } \\
\text { Library Staff }\end{array}$ & Total \\
\hline Humanities* & 3 & 6 & 17 & 0 & 26 \\
Social sciencest & 5 & 22 & 29 & 0 & 56 \\
Natural sciencesł & 1 & 6 & 2 & 0 & 9 \\
Undeclared/not applicable & 1 & 4 & 1 & 6 & 12 \\
Total & 10 & 38 & 49 & 6 & 103 \\
\hline
\end{tabular}

* Departments in the humanities category included English, Slavic languages, Romance languages, German, classics, history, art, art history, music, philosophy, and religious studies.

† Departments in the social sciences category included anthropology, sociology, psychology, clinical psychology, business, economics, political science, international studies, womens' studies, education, information and library science, journalism, RTVMP (radio, television, and motion pictures), and leisure studies.

¥ Departments in the natural sciences category included biology, physical education, geography, medicine, nursing, psychiatry, and pharmacy. 
Because this was a pilot study intended to design an interview protocol, the questions asked in the three phases varied slightly. Wording was changed or response categories were added as data were collected. Whenever possible, earlier open-ended responses were categorized based on the final form of the interview schedule. The fact that this was a pilot study also affected analysis of the data. Initially respondents were considered the unit of analysis, but later it became clear that the item sought was also an appropriate unit of analysis. Unfortunately, some per-item data from the first phase was unavailable.

Of the people conducting known-item searches, 57 had written information describing 338 items. They were catego- rized as having hand-written notes; informal bibliographies, including class reading lists; or published references, bibliographies, and search printouts. The other 46 people, searching for 48 items, did not have any written description of the item(s). The type of item sought and the form of the information known is displayed in table 4 . Most of the items sought were books and journals. Most of the journal citations were drawn from published bibliographies or CD-ROM searches. All the videos sought were from a list provided by a faculty member.

Respondents knew the title for 94 percent of the items sought (see table 5). Publication date was known for 70 percent of all the items and for 97 percent of

TABLE 4

TYPE OF ITEM SOUGHT BY FORM OF INFORMATION KNOWN

\begin{tabular}{lccccc}
\hline $\begin{array}{l}\text { Type of } \\
\text { Item Sought }\end{array}$ & $\begin{array}{c}\text { Recalled from } \\
\text { Memory }\end{array}$ & $\begin{array}{c}\text { Hand-written } \\
\text { Notes }\end{array}$ & $\begin{array}{c}\text { Informal } \\
\text { Bibliographies }\end{array}$ & $\begin{array}{c}\text { Bibliographic Search } \\
\text { Results or Published } \\
\text { References }\end{array}$ & Total \\
\hline Book & 41 & 60 & 78 & 61 & 240 \\
Journal & 6 & 20 & 11 & 74 & 111 \\
Video & 0 & 0 & 0 & 13 & 33 \\
Other & 1 & 0 & 122 & 136 & 2 \\
Total & 48 & 80 & & & 386 \\
\hline
\end{tabular}

TABLE 5

BIBLIOGRAPHIC INFORMATION KNOWN ABOUT THE DESIRED ITEM

\begin{tabular}{|c|c|c|c|c|c|c|c|c|c|c|}
\hline \multirow{2}{*}{$\begin{array}{l}\text { Data Element } \\
\text { Author(s) }\end{array}$} & \multicolumn{2}{|c|}{$\begin{array}{l}\text { Recalled } \\
\text { from } \\
\text { Memory }\end{array}$} & \multicolumn{2}{|c|}{$\begin{array}{c}\text { Hand-written } \\
\text { Notes }\end{array}$} & \multicolumn{2}{|c|}{$\begin{array}{c}\text { Informal } \\
\text { Bibliographies }\end{array}$} & \multicolumn{2}{|c|}{$\begin{array}{c}\text { Bibliographic Search } \\
\text { Results or Published } \\
\text { References }\end{array}$} & \multicolumn{2}{|c|}{$\begin{array}{c}\text { Items from All } \\
\text { Sources }\end{array}$} \\
\hline & 28 & $58 \%$ & 48 & $60 \%$ & 65 & $53 \%$ & 41 & $31 \%$ & 182 & $48 \%$ \\
\hline Editor(s) & 2 & $4 \%$ & 4 & $5 \%$ & 14 & $11 \%$ & 11 & $8 \%$ & 31 & $8 \%$ \\
\hline Title or partial title & 33 & $69 \%$ & 73 & $91 \%$ & 122 & $100 \%$ & 132 & $100 \%$ & 360 & $94 \%$ \\
\hline Publisher* & 3 & $6 \%$ & 22 & $28 \%$ & 36 & $30 \%$ & 40 & $31 \%$ & 101 & $27 \%$ \\
\hline Date of publication ${ }^{*}$ & 4 & $8 \%$ & 45 & $56 \%$ & 92 & $75 \%$ & 128 & $97 \%$ & 269 & $70 \%$ \\
\hline Subject ${ }^{*}$ & 9 & $19 \%$ & 5 & $6 \%$ & 33 & $27 \%$ & 47 & $36 \%$ & 94 & $25 \%$ \\
\hline Page number(s) & 1 & $2 \%$ & 10 & $13 \%$ & 11 & $9 \%$ & 78 & $59 \%$ & 100 & $26 \%$ \\
\hline Other & 6 & $13 \%$ & 3 & $4 \%$ & 35 & $29 \%$ & 7 & $5 \%$ & 51 & $13 \%$ \\
\hline $\begin{array}{l}\text { Total items from } \\
\text { each source } \dagger\end{array}$ & 48 & & 80 & & 122 & & 132 & & 382 & \\
\hline
\end{tabular}

Total number of items analyzed $=382$. Data from four of the respondents in the first phase could not be analyzed.

* Data on publisher, subject and other information from a fifth respondent could not be analyzed, so the base number of items in those categories was 381 .

† A respondent may know more than one data element per item, so the column total will be greater than the total number of items. The percentages reported use the total number of items from each source as the denominator. 
the items for which the respondent had a published record of the citation. The author's name was known for almost half the items. The page number was known for over half of the items where the respondent was consulting a published reference list or the output of a computer-assisted bibliographic search. Other frequently known data elements included the subject and publisher. All of these data elements would be available to someone conducting an OPAC search.
Data elements known for books differed from those known for journals (see tables 6 and 7). Titles were known for virtually all items - both books and journals. Authors were usually known for books, but were not relevant when seeking the location of a journal. Publication date was almost always known for journals, but was known for only about half of the books. Page numbers were known for 80 percent of the journal items sought, but for only 4 percent of the

TABLE 6

BIBLIOGRAPHIC INFORMATION KNOWN ABOUT BOOKS

\begin{tabular}{|c|c|c|c|c|c|c|c|c|c|c|}
\hline \multirow{2}{*}{$\begin{array}{l}\text { Data Element } \\
\text { Author(s) }\end{array}$} & \multicolumn{2}{|c|}{$\begin{array}{c}\text { Recalled from } \\
\text { Memory }\end{array}$} & \multicolumn{2}{|c|}{$\begin{array}{c}\text { Hand-written } \\
\text { Notes }\end{array}$} & \multicolumn{2}{|c|}{$\begin{array}{c}\text { Informal } \\
\text { Bibliographies }\end{array}$} & \multicolumn{2}{|c|}{$\begin{array}{c}\text { Bibliographic Search } \\
\text { Results or Published } \\
\text { References }\end{array}$} & \multicolumn{2}{|c|}{$\begin{array}{l}\text { Items from } \\
\text { All Sources }\end{array}$} \\
\hline & 28 & $68 \%$ & 47 & $78 \%$ & 65 & $83 \%$ & 41 & $72 \%$ & 181 & $77 \%$ \\
\hline Editor(s) & 2 & $5 \%$ & 4 & $7 \%$ & 14 & $18 \%$ & 10 & $18 \%$ & 30 & $13 \%$ \\
\hline Title or partial title & 26 & $63 \%$ & 53 & $88 \%$ & 78 & $100 \%$ & 57 & $100 \%$ & 214 & $91 \%$ \\
\hline Publisher & 2 & $5 \%$ & 22 & $37 \%$ & 36 & $46 \%$ & 38 & $67 \%$ & 98 & $42 \%$ \\
\hline Date of publication & 3 & $7 \%$ & 25 & $42 \%$ & 50 & $64 \%$ & 55 & $96 \%$ & 133 & $56 \%$ \\
\hline Subject & 8 & $20 \%$ & 3 & $5 \%$ & 25 & $32 \%$ & 40 & $70 \%$ & 76 & $32 \%$ \\
\hline Page number(s) & 1 & $2 \%$ & 2 & $3 \%$ & 1 & $1 \%$ & 6 & $11 \%$ & 10 & $4 \%$ \\
\hline Other* & 5 & $13 \%$ & 2 & $3 \%$ & 2 & $3 \%$ & 5 & $9 \%$ & 14 & $6 \%$ \\
\hline $\begin{array}{l}\text { Total from each } \\
\text { source } \dagger\end{array}$ & 41 & & 60 & & 78 & & 57 & & 236 & \\
\hline
\end{tabular}

Total number of items analyzed $=236$. Data from four of the respondents in the first phase could not be analyzed.

* Data on other information known about journals from one additional respondent could not be analyzed.

† A respondent may know more than one data element per item, so the column total will be greater than the total number of items. The percentages reported use the number of items from each source as the denominator.

TABLE 7

BIBLIOGRAPHIC INFORMATION KNOWN ABOUT JOURNALS

\begin{tabular}{|c|c|c|c|c|c|c|c|c|c|c|}
\hline \multirow{2}{*}{$\begin{array}{l}\text { Data Element } \\
\text { Author(s) }\end{array}$} & \multicolumn{2}{|c|}{$\begin{array}{l}\text { Recalled from } \\
\text { Memory }\end{array}$} & \multicolumn{2}{|c|}{$\begin{array}{l}\text { Hand-written } \\
\text { Notes }\end{array}$} & \multicolumn{2}{|c|}{$\begin{array}{c}\text { Informal } \\
\text { Bibliographies }\end{array}$} & \multicolumn{2}{|c|}{$\begin{array}{c}\text { Bibliographic Search } \\
\text { Results or Published } \\
\text { References }\end{array}$} & \multicolumn{2}{|c|}{$\begin{array}{c}\text { Items from All } \\
\text { Sources }\end{array}$} \\
\hline & 0 & & 1 & $5 \%$ & 0 & & 0 & & 1 & $1 \%$ \\
\hline Editor(s) & 0 & & 0 & & 0 & & 0 & & 0 & 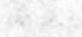 \\
\hline Title or partial title & 6 & $100 \%$ & 20 & $100 \%$ & 11 & $100 \%$ & 74 & $100 \%$ & 111 & $100 \%$ \\
\hline Publisher & 1 & $17 \%$ & 0 & & 0 & & 1 & $1 \%$ & 2 & $2 \%$ \\
\hline Date of publication & 1 & $17 \%$ & 20 & $100 \%$ & 9 & $82 \%$ & 72 & $97 \%$ & 102 & $92 \%$ \\
\hline Subject & 0 & & 2 & $10 \%$ & 8 & $73 \%$ & 7 & $9 \%$ & 17 & $15 \%$ \\
\hline Page number(s) & 0 & & 8 & $40 \%$ & 10 & $91 \%$ & 71 & $96 \%$ & 89 & $80 \%$ \\
\hline Other & 1 & $17 \%$ & 1 & $5 \%$ & 0 & & 2 & $3 \%$ & 4 & $4 \%$ \\
\hline $\begin{array}{l}\text { Total from each } \\
\text { source* }\end{array}$ & 6 & & 20 & & 11 & & 74 & & 111 & \\
\hline
\end{tabular}

Total number of items analyzed $=111$.

* A respondent may know more than one data element per item, so the column total will be greater than the total number of items. The percentages reported use the number of items from each source as the denominator. 
books. When considering the user's purposes in searching the online catalog for these types of items, such differences are not surprising.

The origin of the information known by the user was analyzed in table 8 . Onequarter of the items were identified through CD-ROM searches. Professors/ teachers (16 percent) and class reading lists (13 percent) also were mentioned frequently. For those people without written information, prior use of the item was mentioned frequently. In addition to these common information sources, responses such as overdue notices and publishers' flyers were categorized as "other."
Each respondent reported the purpose of the search (see table 9). Completing a class assignment was the reason mentioned most frequently for needing an item, accounting for almost half the items. Other research, such as proposal writing, presentations, or editing a work, was also common, as were preparing a dissertation or thesis and studying for comprehensive exams. Personal use or leisure reading was most common among people who did not have written information, and studying for comprehensive exams was most common among people using informal bibliographies.

TABLE 8

ORIGIN OF BIBLIOGRAPHIC INFORMATION

\begin{tabular}{|c|c|c|c|c|c|c|c|c|c|c|}
\hline \multirow{2}{*}{$\begin{array}{l}\text { Origin of } \\
\text { Bibliographic Data }\end{array}$} & \multicolumn{2}{|c|}{$\begin{array}{c}\text { Recalled from } \\
\text { Memory }\end{array}$} & \multicolumn{2}{|c|}{$\begin{array}{c}\text { Hand-written } \\
\text { Notes }\end{array}$} & \multicolumn{2}{|c|}{$\begin{array}{c}\text { Informal } \\
\text { Bibliographies }\end{array}$} & \multicolumn{2}{|c|}{$\begin{array}{c}\text { Bibliographic Search } \\
\text { Results or Published } \\
\text { References }\end{array}$} & \multicolumn{2}{|c|}{$\begin{array}{c}\text { Items from All } \\
\text { Sources }\end{array}$} \\
\hline & 9 & $21 \%$ & 13 & $17 \%$ & 35 & $29 \%$ & 2 & $1 \%$ & 59 & $16 \%$ \\
\hline Class reading list & 6 & $14 \%$ & 12 & $16 \%$ & 30 & $25 \%$ & 0 & & 48 & $13 \%$ \\
\hline Reference in book & 2 & $5 \%$ & 14 & $19 \%$ & 0 & & 4 & $3 \%$ & 20 & $5 \%$ \\
\hline Reference in journal & 1 & $2 \%$ & 23 & $31 \%$ & 0 & & 4 & $3 \%$ & 28 & $7 \%$ \\
\hline CD ROM search & 1 & $2 \%$ & 10 & $13 \%$ & 0 & s & 82 & $60 \%$ & 93 & $25 \%$ \\
\hline Friend & 2 & $5 \%$ & 2 & $3 \%$ & 0 & & 0 & & 4 & $1 \%$ \\
\hline Used item before & 7 & $17 \%$ & 0 & & 0 & & 3 & $2 \%$ & 10 & $3 \%$ \\
\hline Saw item before & 3 & $7 \%$ & 1 & $1 \%$ & 1 & $1 \%$ & 0 & & 5 & $1 \%$ \\
\hline Other & 11 & $26 \%$ & 0 & & 56 & $46 \%$ & 41 & $30 \%$ & 108 & $29 \%$ \\
\hline $\begin{array}{l}\text { Total number } \\
\text { of items }\end{array}$ & 42 & & 75 & & 122 & & 136 & & 375 & \\
\hline
\end{tabular}

Total number of items analyzed $=375$. Information about the origin of the information was not provided for 11 of the items.

TABLE 9

PURPOSE OF SEARCH

\begin{tabular}{|c|c|c|c|c|c|c|c|c|c|c|}
\hline \multirow{2}{*}{$\begin{array}{l}\text { Purpose of Search } \\
\text { Class assignment }\end{array}$} & \multicolumn{2}{|c|}{$\begin{array}{l}\text { Recalled from } \\
\text { Memory }\end{array}$} & \multicolumn{2}{|c|}{$\begin{array}{l}\text { Hand-written } \\
\text { Notes }\end{array}$} & \multicolumn{2}{|c|}{$\begin{array}{c}\text { Informal } \\
\text { Bibliographies }\end{array}$} & \multicolumn{2}{|c|}{$\begin{array}{c}\text { Bibliographic Search } \\
\text { Results or Published } \\
\text { References }\end{array}$} & \multicolumn{2}{|c|}{$\begin{array}{c}\text { Items from All } \\
\text { Sources }\end{array}$} \\
\hline & 22 & $46 \%$ & 38 & $48 \%$ & 29 & $24 \%$ & 91 & $67 \%$ & 180 & $47 \%$ \\
\hline Other research & 5 & $10 \%$ & 25 & $31 \%$ & 25 & $21 \%$ & 11 & $8 \%$ & 66 & $17 \%$ \\
\hline Dissertation/thesis & 2 & $4 \%$ & 12 & $15 \%$ & 0 & & 26 & $19 \%$ & 40 & $10 \%$ \\
\hline Comprehensive exams & 1 & $2 \%$ & 0 & & 32 & $26 \%$ & 0 & & 33 & $9 \%$ \\
\hline Preparation for class & 4 & $8 \%$ & 0 & & 1 & $1 \%$ & 4 & $3 \%$ & 9 & $2 \%$ \\
\hline Verify a reference & 1 & $2 \%$ & 2 & $3 \%$ & 1 & $1 \%$ & 0 & & 4 & $1 \%$ \\
\hline Personal use & 8 & $17 \%$ & 3 & $4 \%$ & 0 & & 0 & & 11 & $3 \%$ \\
\hline Other & 5 & $10 \%$ & 0 & & 33 & $27 \%$ & 4 & $3 \%$ & 42 & $11 \%$ \\
\hline $\begin{array}{l}\text { Total number } \\
\text { of items }\end{array}$ & 48 & & 80 & & 121 & & 136 & & 385 & \\
\hline
\end{tabular}

Total number of items analyzed $=385$. Data from one respondent in the first phase could not be analyzed. 
Each respondent was asked to return after completing the search and report whether the desired items were found. Almost all the respondents complied with this request, so the searcher's assessment of his or her success was known for 92 percent of the items. Most catalog users (70 percent) said they found the items they were seeking (see table 10). Surprisingly, the more formal the source of the bibliographic data, the less likely that the user conducted a successful search, with the highest success rate reported for items recalled from memory.

To verify the success rates of the respondents, a member of the research team replicated the search for each item. For 14 items, the search could not be replicated because the respondent did not share the citation details with the researchers. The results from the replicated searches are presented in table 11. The researcher's success rate was very close to that of the original searcher when the original searcher's information matched the catalog record. Four author names, one editor name, and six titles provided by respondents were inaccurate. Additionally, 14 search failures can be attributed to the evolving medium of the catalog, i.e., they were in the collection but had not yet been added to the online catalog. It can be concluded that, with accurate citation data, respondents successfully used the current online catalog for known-item searches.

\section{DISCUSSION}

The purposes of this study were twofold: first, to develop and validate a

TABLE 10

SELF-REPORTED SEARCH SUCCESS

\begin{tabular}{|c|c|c|c|c|c|c|c|c|c|c|}
\hline \multirow{3}{*}{$\begin{array}{l}\text { Successful } \\
\text { Not successful }\end{array}$} & \multicolumn{2}{|c|}{$\begin{array}{l}\text { Recalled from } \\
\text { Memory }\end{array}$} & \multicolumn{2}{|c|}{$\begin{array}{c}\text { Hand-written } \\
\text { Notes }\end{array}$} & \multicolumn{2}{|c|}{$\begin{array}{c}\text { Informal } \\
\text { Bibliographies }\end{array}$} & \multicolumn{2}{|c|}{$\begin{array}{c}\text { Bibliographic Search } \\
\text { Results or Published } \\
\text { References }\end{array}$} & \multicolumn{2}{|c|}{$\begin{array}{c}\text { Items from All } \\
\text { Sources }\end{array}$} \\
\hline & 38 & $84 \%$ & 51 & $72 \%$ & 74 & $69 \%$ & 85 & $65 \%$ & 248 & $70 \%$ \\
\hline & 7 & $16 \%$ & 20 & $28 \%$ & 33 & $31 \%$ & 46 & $35 \%$ & 106 & $30 \%$ \\
\hline $\begin{array}{l}\text { Total items for } \\
\text { which success } \\
\text { was reported }\end{array}$ & 45 & & 71 & & 107 & & 131 & & 354 & \\
\hline $\begin{array}{l}\text { Items for which } \\
\text { success was } \\
\text { not reported }\end{array}$ & 3 & & 9 & & 15 & & 5 & & 32 & \\
\hline
\end{tabular}

TABLE 11

SUCCESS OF REPLICATED SEARCHES

\begin{tabular}{|c|c|c|c|c|c|c|c|c|c|c|}
\hline \multirow{2}{*}{ Successful replications } & \multicolumn{2}{|c|}{$\begin{array}{l}\text { Recalled from } \\
\text { Memory }\end{array}$} & \multicolumn{2}{|c|}{$\begin{array}{c}\text { Hand-written } \\
\text { Notes }\end{array}$} & \multicolumn{2}{|c|}{$\begin{array}{c}\text { Informal } \\
\text { Bibliographies }\end{array}$} & \multicolumn{2}{|c|}{$\begin{array}{c}\text { Bibliographic Search } \\
\text { Results or Published } \\
\text { References }\end{array}$} & \multicolumn{2}{|c|}{$\begin{array}{l}\text { Items from } \\
\text { All Sources }\end{array}$} \\
\hline & & & & & & & & & & \\
\hline Citation correct & 31 & $82 \%$ & 57 & $71 \%$ & 84 & $69 \%$ & 79 & $60 \%$ & 251 & $67 \%$ \\
\hline Citation incorrect & 6 & $16 \%$ & 5 & $6 \%$ & 0 & & 0 & & 11 & $3 \%$ \\
\hline Citation in prior catalog & 0 & & 2 & $3 \%$ & 0 & & 12 & $9 \%$ & 14 & $4 \%$ \\
\hline \multicolumn{11}{|l|}{ Unsuccessful replications } \\
\hline Item not in collection & 1 & $3 \%$ & 16 & $20 \%$ & 38 & $31 \%$ & 41 & $31 \%$ & 96 & $26 \%$ \\
\hline Total searches replicated & 38 & & 80 & & 122 & & 132 & & 372 & \\
\hline $\begin{array}{l}\text { Items not replicated } \\
\text { (citation not known) }\end{array}$ & 10 & & 0 & & 0 & & 4 & & 14 & \\
\hline
\end{tabular}


method for collecting data concerning the information known by online catalog users and, second, to provide preliminary data concerning that information. It was successful in each of these two objectives.

The methodological result of the study is a structured interview protocol that can be used to gather data concerning the information possessed by online catalog users. The protocol (in the appendix) first identifies those users intending to conduct a known-item search, then asks about the information possessed by the respondent, the source of that information, and the purpose(s) of the search. Next, it covers the academic status and discipline of the respondent. Finally, it asks for the respondent's perspective on the success of the search. The use of a desktop photocopier in conjunction with the interview was found to be an efficient and cost-effective means of accurately capturing written or printed citation data possessed by the respondent.

Because this was a pilot study of a small sample, the results may not be generalizable beyond the current respondents. Some preliminary conclusions about catalog use can, however, be drawn. First, of the 160 catalog users who did not decline participation, only 36 percent were conducting subject searches; the remaining 64 percent were conducting known-item searches. Second, the information about an item may be recalled from memory or recorded in hand-written notes, but most often (for 67 percent of the items) it is more formal, such as a class reading list or output from a bibliographic search. Third, known-item searches are primarily for books (about two-thirds) and journals (about one-third), and the data elements known about an item vary by the item's form. Titles are known for either type of item, but authors are known primarily for books, while date and page numbers are known primarily for journals. Fourth, over half the items originated with a professor or teacher, on a class reading list, or on the output from a CD-ROM search. Almost half the searches were conducted in connection with a class assignment. Finally, most (70 percent) of the searches were successful. Only a small proportion of the search failures ( 3 percent) could be attributed to inaccuracies in the information possessed by the respondents, and such inaccuracies occurred only when the re- spondent depended on his or her memory or hand-written notes.

The fact that these respondents were searching on recently implemented software had no detectable negative effect. Excluding collection failures, the few search failures that occurred can be attributed to inaccuracies in the citations-not to inadequacies in the catalog software. On the other hand, some people may have reported finding the desired item(s), even though they did not find exactly what they wanted, because of frustration with learning a new system. The availability of keyword searching, a new feature to UNC catalog users, may also lead to changes in the information that users bring to the catalog in the future.

A large-scale study based on the method described here could address several issues, such as the variability in the information possessed by catalog users and the accuracy of that information. However, one important question cannot be addressed by an interview: Of the information available, which is most likely to be used in a catalog search? The analysis of transaction logs would complete the picture by allowing connections to be made between the data elements available, the data elements included in the search, and the success of the search. Such an analysis should be integrated with future interview studies of catalog use.

\section{IMPLICATIONS AND CONCLUSION}

The results reported here provide a preliminary picture of the respondents' catalog use. A more complete picture would be provided by the large-scale study described above. Results from the large-scale study could be used to improve online catalogs by focusing our attention on those data elements most likely to be included in searches. In essence, the results could provide the 
basis for decisions concerning the reduction of effort expended in descriptive cataloging.

However, there is one major shortcoming with this reasoning: it assumes that the primary use of the online catalog is to search for items - either for known items, as discussed in this paper, or for items on a given subject. Analysis of catalog use is incomplete without gathering additional data concerning nonsearch uses of the catalog, some of which may be specific to subsets of the user audience (e.g., a humanities scholar's use of details about the edition of an item). This study has not taken into account the existence of such vari- ations in catalog use, and the method described here will not be effective in studying the frequency or quality of alternative uses. It is important to keep in mind that these results are limited to an examination of catalog searches.

Studies of catalog use from the user's perspective are important for the improvement of the services that libraries can offer. A long tradition of practice, based on the perspectives of professionals, is not a strong basis for the design of online catalogs. Instead, a user-oriented perspective should be adopted, so that we can design catalogs that further our primary goal: providing access to the intellectual content sought by our clients.

\section{REFERENCES AND NOTES}

1. Ruth C. T. Morris, "Toward a User-Centered Information Service," Journal of the American Society for Information Science 45 (Jan. 1994): 20-30.

2. Joseph R. Matthews, Gary S. Lawrence, and Douglas K. Ferguson, eds., Using Online Catalogs: A Nationwide Survey. A Report of a Study Sponsored by the Council on Library Resources (New York: Neal-Schuman, 1983); Gary S. Lawrence, Vicki Graham, and Heather Presley, "University of California Users Look at MELVYL: Results of a Survey of Users of the University of California Prototype Online Union Catalog," in Advances in Library Administration and Organization: A Research Annual, vol. 3, ed. Gerard B. McCabe and Bernard Kreissman (Greenwich, Conn.: JAI Pr., 1984), 85-208.

3. Micheline Hancock-Beaulieu, Stephen Robertson, and Colin Neilson, "Evaluation of Online Catalogues: Eliciting Information from the User," Information Processing \& Management 27 (1991): 523-32.

4. John Akeroyd, "Information Seeking in Online Catalogues," Journal of Documentation 46 (Mar. 1990): 33-52.

5. Grace Agnew, Albert Camp, Mary Nell Maule, and Jane Richards, "The Online Catalog and Patron Search Strategies at Georgia State University," Georgia Librarian 23 (May 1986): 42-44.

6. Hancock-Beaulieu, Robertson, and Neilson, "Evaluation of Online Catalogues."

7. Ben-Ami Lipetz, User Requirements in Identifying Desired Works in a Large Library, Final Report for Grant No. SAR/OEG-1-71071140-4427 (Washington, D. C.: U.S. Department of Health, Education and Welfare, Office of Education, Bureau of Research; New Haven, Conn.: Yale University Library, June 1970).

8. James Krikelas, "Searching the Library Catalog-AStudy of Users' Access," Library Research 2 (Fall 1980): 215-30.

9. Renata Tagliacozzo, Lawrence Rosenberg, and Manfred Kochen, "Access and Recognition: From Users' Data to Catalogue Entries," Journal of Documentation 26 (Sept. 1970): 230-49.

10. Rhonda N. Hunter, "Successes and Failures of Patrons Searching the Online Catalog at a Large Academic Library: A Transaction Log Analysis," RQ 30 (Spring 1991): 395-402.

11. Steven D. Zink, "Monitoring User Search Success through Transaction Log Analysis: The WolfPAC Example," Reference Services Review 19 (Spring 1991): 49-56.

12. Akeroyd, "Information Seeking in Online Catalogues."

13. Thomas A. Peters, "When Smart People Fail: An Analysis of the Transaction Log of an Online Public Access Catalog," Journal of Academic Librarianship 15 (Nov. 1989): 267-73.

14. David Holmes and Derrick Bulger, "A Day in the Life of a Public Terminal-A Transaction Analysis of an Online Catalogue Terminal in a Bilingual Environment," Canadian Journal for Information Science 13 (Dec. 1988): 21-33. 
15. Nien-tzu Nancy Chang, "User's Search Behavior on an Online Catalog: A Preliminary Transaction Log Study" (master's paper, University of North Carolina at Chapel Hill, November 1986).

16. Matthews, Lawrence, and Ferguson, Using Online Catalogs.

17. John E. Tolle, Current Utilization of Online Catalogs: Transaction Log Analysis, Final Report to the Council on Library Resources, vol. 1 (Dublin, Ohio: OCLC Online Computer Library Center, 1983).

18. Akeroyd, "Information Seeking in Online Catalogues."

19. Holmes and Bulger, "A Day in the Life of a Public Terminal."

20. Tolle, Current Utilization of Online Catalogs.

21. Matthews, Lawrence, and Ferguson, Using Online Catalogs.

22. Akeroyd, "Information Seeking in Online Catalogues."

23. Ibid.

24. Peters, "When Smart People Fail."

25. Holmes and Bulger, "A Day in the Life of a Public Terminal."

26. Matthews, Lawrence, and Ferguson, Using Online Catalogs.

27. Sammy R. Alzofon and Noelle Van Pulis, "Patterns of Searching and Success Rates in an Online Public Access Catalog," College \& Research Libraries 45 (Mar. 1984): 110-15.

28. Lawrence, Graham, and Presley, "University of California Users."

29. Lawrence, Graham, and Presley, "University of California Users"; Matthews, Lawrence, and Ferguson, Using Online Catalogs.

30. Lipetz, User Requirements in Identifying Desired Works.

31. David Barnes Bennett, "BIS Online Catalog Use: A Transaction Log Analysis" (master's paper, University of North Carolina at Chapel Hill, April 1987); Laurie L. Weakley, "Online Catalog Use: A Transaction Log Analysis" (master's paper, University of North Carolina at Chapel Hill, July 1989).

32. Mary Noel Gouke and Sue Pease, "Title Searches in an Online Catalog and a Card Catalog: A Comparative Study of Patron Success in Two Libraries," Journal of Academic Librarianship 8 (July 1982): $137-43$.

33. Matthews, Lawrence, and Ferguson, Using Online Catalogs.

34. Christine L. Borgman, End User Behavior on the Ohio State University Libraries' Online Catalog: A Computer Monitoring Study, Research Report Prepared for OCLC (Dublin, Ohio: OCLC Online Computer Library Center, 1983).

35. Gouke and Pease, "Title Searches in an Online Catalog and a Card Catalog."

36. Jean Dickson, "An Analysis of User Errors in Searching an Online Catalog," Cataloging \& Classification Quarterly 4 (Spring 1984): 19-38.

37. Jerry Specht, "Patron Use of an Online Circulation System in Known-Item Searching," Journal of the American Society for Information Science 31 (Sept. 1980): 335-46.

38. Dickson, "An Analysis of User Errors."

39. Arlene G. Taylor, "Authority Files in Online Catalogs: An Investigation of Their Value," Cataloging \& Classification Quarterly 4 (Spring 1984): 1-17.

40. Peters, "When Smart People Fail."

41. Zink, "Monitoring User Search Success."

42. Alexandra Dimitroff, "Mental Models Theory and Search Outcome in a Bibliographic Retrieval System," Library \& Information Science Research 14 (April/June 1992): 141-56.

43. Holmes and Bulger, "A Day in the Life of a Public Terminal"; Janet Kinsella and Philip Bryant, "Online Public Access Catalog Research in the United Kingdom: An Overview," Library Trends 35 (Spring 1987): 619-29.

44. Borgman, End User Behavior.

45. Bennett, "BIS Online Catalog Use"; Weakley, "Online Catalog Use."

46. Dickson, "An Analysis of User Errors"; Taylor, "Authority Files in Online Catalogs."

47. Peters, "When Smart People Fail."

48. Zink, "Monitoring User Search Success."

49. Ibid.

50. Dickson, "An Analysis of User Errors"; Taylor, "Authority Files in Online Catalogs."

51. Peters, "When Smart People Fail."

52. Holmes and Bulger, "A Day in the Life of a Public Terminal."

53. Bennett, "BIS Online Catalog Use"; Weakley, "Online Catalog Use."

54. Dickson, "An Analysis of User Errors." 
55. Matthews, Lawrence, and Ferguson, Using Online Catalogs; Lawrence, Graham, and Presley, "University of California Users."

56. Holmes and Bulger, "A Day in the Life of a Public Terminal."

57. Specht, "Patron Use of an Online Circulation System."

58. Tagliacozzo, Rosenberg, and Kochen, "Access and Recognition"; Lipetz, User Requirements in Identifying Desired Works.

59. Matthews, Lawrence, and Ferguson, Using Online Catalogs.

60. Lipetz, User Requirements.

61. Tagliacozzo, Rosenberg, and Kochen, "Access and Recognition."

62. Ibid., 234.

63. Ann T. Curran and Henriette D. Avram, The Identification of Data Elements in Bibliographic Records, Final Report of the Special Project on Data Elements (United States of America Standards Institute, Sectional Committee on Library Work and Documentation (Z-39), Subcommittee on Machine Input Records (SC-2), May 1967).

64. Matthews, Lawrence, and Ferguson, Using Online Catalogs.

\section{APPENDIX \\ Interview Form for Study of Known-Item Searches}

Date:

Survey \# :

We are conducting a research project on how people use the online catalog. Would you be willing to participate? It will take less than five minutes.

1. What are you looking for today?

$\square$ Subject search (Something on...)

Thank you and stop.

$\square$ Known item (A book, a book by...)

Give the respondent the full consent form.

$\square$ Book $\square$ Journal $\square$ Verify call number

Do you have any questions about the research? I would like to remind you that you may withdraw from the project at any time.

2. Did you bring any written information about the book/article with you?

$\square$ Yes. May I see the information and make a copy of it?

No. What do you know about the item?
$\square$ Author
$\square$ Author and title
$\square$ Title
$\square$ Editor
$\square$ Part of the title
$\square$ Subject:

Is there anything else you know about the item?

3. Where did you get this information?

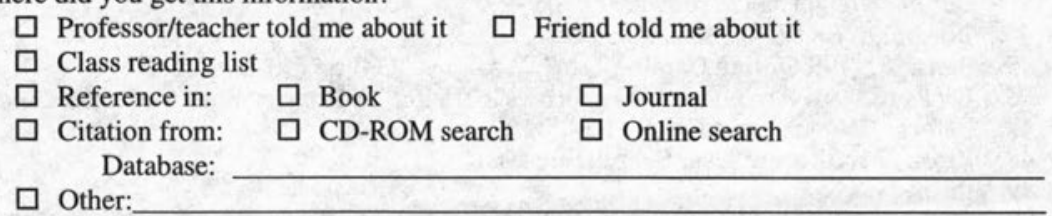

4. What will you be using the book/article for?
$\square$ Class assignment
$\square$ Dissertation/thesis
$\square$ Course preparation
$\square$ Verify reference(s) for publication
$\square$ Personal
$\square$ Other research
Other: 
5. I need to get some basic information about you. Are you a student or faculty member?

$\square$ Undergraduate student

$\square$ Student from another school:

What department are you in?

$\square$ Faculty

$\square$ Faculty from another school:

What department are you in?

$\square$ Member of local community

Other: $\square$ Graduate student

Independent researcher/scholar

6. When you're finished using the online catalog, will you please come back and let me know whether you found the book/article in the catalog?

Time for start of search:

Time for return:

After the search:

7. Did you find what you were looking for?

$\square$ Yes

Did you get:

$\square$ More than you needed

$\square$ Exactly what you needed

$\square$ Not what you were looking for, but similar items that will satisfy your need.

$\square$ It was in another library. Which?

$\square$ Other:

$\square$ No

$\square$ We don't own it.

$\square$ It was checked out.

Other:

\section{COLLEGE \& RESEARCH LIBRARIES} INDEX TO ADVERTISERS

ALA

Biosis

Blackwell

Ebsco Subscription

Service

InfoEN Associates

Library Technologies

OCLC

PAIS

Personal Bibliographic Software

Readmore

Todd

H. W. Wilson
193

cover 3

194

189

257

248

220

cover 2, 191

197

198,292

cover 4

285, 287 